\title{
Microfinance and Livelihood Development in Poor Coastal Communities in Eastern Sri Lanka
}

\author{
M. Thilepan and S. Thiruchelvam ${ }^{1 *}$ \\ Postgraduate Institute of Agriculture \\ University of Peradeniya \\ Sri Lanka
}

\begin{abstract}
Various organizations are involved in micro-financial programmes in Sri Lanka. There is limited knowledge on the impact of microfinance on the livelihood improvements among poor coastal communities who were affected by Tsunami in Eastern Sri Lanka. This study investigated the effectiveness of microfinance support for coastal communities' livelihood development in Trincomalee. A survey was conducted using stratified randomly selected 99 microfinance beneficiary households in three identified coastal villages in three Grama Niladhari Divisions in Kinniya. The analysis was based on 2006 information as a benchmark. The analysis was conducted using a multiple linier regression with the factors determining the revolving fund efficiency (RFE). The study found an average of $39.5 \%$ and $14.2 \%$ increase in income and private savings, respectively in agriculture sectors. Although the poor and the poorest groups have been reached by microfinance institutions, $65 \%$ of their clients seem to be from the non-poor groups. About $90 \%$ of the young people reported lack of opportunities for modern livelihood supports. The RFE was $0.32 \%$ indicating that it was not well adopted in practice. This may be due to lack of responsiveness of the Community Based Organizations (CBO). The results of multiple regression analysis showed that age, education and family income and weakly facilitated RFE was affected significantly by private savings. To improve livelihoods of poor coastal communities, effective capacity building of $C B O$ s on microfinance management, training and technical supports to young people in alternative non traditional livelihoods and creating market opportunities are important.
\end{abstract}

Key words: Livelihood, Microfinance, Coastal Communities, Eastern Sri Lanka

\section{INTRODUCTION}

Credit is often seen as an indispensable vehicle for the poor to alleviate hunger and poverty, however, it has its own drawbacks. Microfinance is provision of small credit to the poor without securing collaterals. Microfinance, along with savings and micro-insurance products, is meant to provide financial services to the poorest who do not have access to formal financial institutions. Thus, the beneficiaries are not only safeguarded from money lenders, but also get an opportunity to develop as micro-entrepreneurs (ProMiS, 2007).

In Sri Lanka anecdotal evidence has shown that there were widespread livelihood issues. The rural poor have no easy access to get loans and grants from commercial banks or financial

To whom correspondence should be addressed: sthiru@pdn.ac.lk

Department of Agricultural Economics and Business Management, Faculty of Agriculture, University of

Peradeniya, Peradeniya, Sri Lanka 
structures, because they have lack of collaterals and business plans. There is a gap between what poor people need and what they have access to (ILO, 2006). Tilakaratna et al. (2005) showed that microfinance has helped households in middle quintiles to increase their income and helped the very poor to increase consumption expenditure.

The Northern and Eastern Province coastal area covered 2/3 of the coastal zone in Sri Lanka. Under Tsunami recovery activities most of the government and Nongovernment organizations (NGO) supported coastal communities to recover their livelihoods by giving micro-credits through banks and semi-governmental projects. Experiences show the prevalence of weak regulatory framework, lack of legal structure for International NGOs and the target orientation activities had not contributed community self reliance. Due to unplanned activities over extraction of fishing and coastal depletion was the outcome (ITDGSouth Asia, 2005)

The government and foreign funded projects give their micro-credit directly and recover them directly without revolving to saving groups. This microcredit grant was non recoverable by the projects but it was revolved within the saving groups with small interest rate (Tsunami Affected Area Project, TAAP 2005).

Provision of microfinance for the poorest segment is mainly carried out by the government such as Samurdhi, Sanasa and cooperative, rural development banks (ILO, 2006). According to a recent report, Samurdhi members are ultra poor with nearly $60 \%$ of them borrowing from Samurdhi, $50 \%$ of the recipients of Samurdhi are at the breakeven while $40 \%$ of the members borrowing from friends and relatives (Economic and Social Statistics of Sri Lanka, 2009). Despite the large number of institutions providing micro-credit services particularly to the poor coastal communities, there is limited knowledge on the impact of microfinance on livelihood improvement and savings habits of poor rural coastal communities in Eastern Sri Lanka.

In the above context, this study is mainly focused on investigating the livelihood gaps among the poor coastal communities who received microfinance under the post-Tsunami recovery activities assistance programmes in Kinniya DS division of the Trincomalee district.

\section{METHODOLOGY}

Trincomalee is the central district in Eastern province. Industries such as Prima, Mistui cement factory and Cod Bay harbour, and some archeological places are located in Trincomalee. In here mostly all types of ethnic people were affected by Tsunami in 2004. There were four divisional secretariats viz. Kuchchaveli, Town and Gravets, Kinniya and Muthur which were highly affected by Tsunami in 2004.

A total of 99 recipients of microfinance were stratified according to the livelihood activities and with 33 individual households were randomly selected from three villages in the Kinniya Divisional Sectary Division (DSD) in 2009. To share the knowledge of the area, and discuss the issues related to microfinance, key informant interviews were also held with Community Based Organizations (CBO), Rural Development Officers and Grama Sevaka Officer (GSO) in the selected villages. Information on socio-demographic and economic information, knowledge about the coastal resources, livelihood pattern, microfinance institutional support, among others were collected through questionnaire survey. Crops, livestock and fishery sector status and income data were collected. 
Microfinance distribution is organized through CBOs, which should be able to meet their members' credit requirements and to assist them in taking up a wide range of income generation activities. The revolving seed money in income generation activities is shown in Fig. 1.

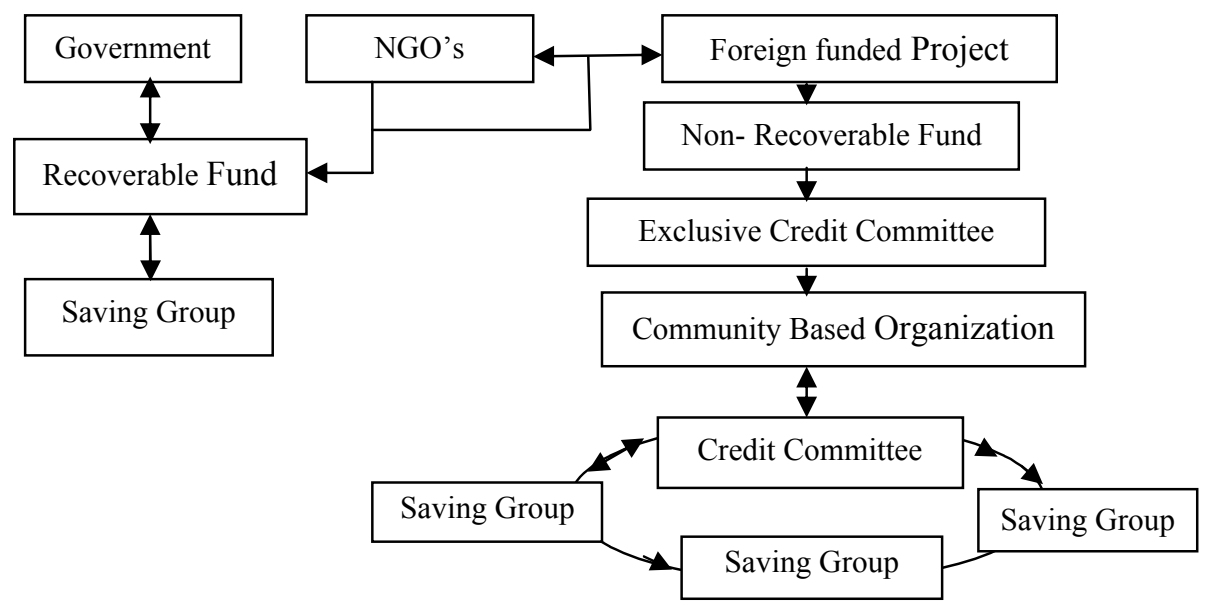

\section{Fig. 1. Framework for microfinance support in funding agencies}

Information on income before micro-credit was obtained from the baseline study carried out by the Costal Conservation Department (2006). Paired t- test was used to measure the level of significance between base year 2006 as before situation with after micro-credit support situation in 2008. CBOs' revolving fund efficiency was calculated using the formula mentioned below.

Revolving Fund Efficiency $($ RFE) $=($ Due Repayment / Due Installment) $x 100$

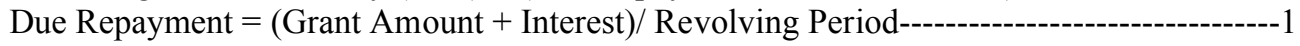

The average income increases after six months was used as revolving efficiency and it was also expected to increase with time. Further, since monthly expenditure also influences the cash balance in the family, saving was also included in this calculation. Revolving period, interest rate, amount of micro-credit support, amount of repayment pattern on the loan holders and family social status were expected to influence the revolving efficiency. The study hypothesized that revolving fund efficiency was independent of socio-economic and external factors. The following multiple linear regression model was used for empirical estimation:

$$
\begin{aligned}
\mathrm{RFE}= & \beta 0+\beta_{1} \mathrm{AG}+\beta_{2} \mathrm{ED}+\beta_{3} \mathrm{EX}+\beta_{4} \mathrm{FS}+\beta_{5} \mathrm{FI}+\beta_{6} \mathrm{MF}+\beta_{7} \mathrm{IR}+\beta_{8} \mathrm{RP}+-\cdot-\cdot--\cdot-------2 \\
& \beta_{9} \mathrm{SA}+\mathrm{e}
\end{aligned}
$$

Where RFE - Revolving fund efficiency, AG - Age of household head in years, FS Family Size, ED- Education in years of schooling of the household head, EX - Experience in farming in years, FI - Average family income per season, MC - Amount of microfinancé received in Rs., IR- Interest Rate in \%, AD - Revolving period in months, SA - Saving amount in Rs, , e - random error term of the regression model. 


\section{RESULTS AND DISCUSSION}

\section{Characteristics of coastal community}

The study revealed that all respondents belonged to Muslims (moor) community. The average family size in the area was five members per family. The age group $15-65$ years dominates, accounting nearly for $50 \%$ of the population. While the category belonging to population above 65 years of age was almost non-existent at present, those below 15 years of age accounts for approximately $50 \%$ of the population. The average household head age was nearly 41 years. The average household's income was around Rs. 13,772.00 per month and about $43.13 \%$ of them were below poverty line of Rs. 4843 real total expenditure per person per month (2006/07). About 28, 18, 14, 9, 7 and 2\% were farm labourers, unemployed, public sector, private sector employed, foreign income recipients and non farm labourers respectively.

\section{Microfinance service}

Communities received around 64, 18, 9 and 9\% of their credit from CBO, Peoples Bank, Bank of Ceylon, and Co-op Rural Bank, respectively. The major reason for significantly higher share of CBO was due to all the NGOs and Foreign Funded Projects were conducting their micro credit programmes through CBOs at lower interest rate of $15 \%$ under revolving fund mechanism.

\section{Livelihood improvement and microfinance}

Table 1 summarizes the results of micro-credit impact in traditional sectors namely, farming, livestock and fishery sectors. Table 2 shows that credit had significantly increased the net income from paddy cultivation $(230 \%)$. This was mainly due to increased extent of cultivation from 3.5 to 4.4 ha in 2008 in Kinniya DSD. Other Field Crop (OFC) provided a $75 \%$ increase in income due to an increase of extent of cultivation by $53 \%$. Net income increase in crop cultivation indicates significant impact of micro-credit.

Table 1. Microfinance impact on crop cultivation, livestock production and fishery sectors in Kinniya DSD

\begin{tabular}{lccc}
\hline \multirow{2}{*}{ Sector } & \multicolumn{3}{c}{ The impact of micro-credit on net income Rs/ Season } \\
\cline { 2 - 4 } & Before (2006) & After (2008) & \% Increase \\
\hline Paddy $\left(\mathrm{n}_{1}=18\right)$ & $45,958.00$ & $151,540.00$ & $230(4.03)^{* *}$ \\
OFC $\left(\mathrm{n}_{2}=8\right)$ & $44,500.00$ & $78,021.00$ & $75(4.44)^{* *}$ \\
Goat $\left(\mathrm{n}_{3}=10\right)$ & $8,136.00$ & $15,480.00$ & $90(1.99)^{*}$ \\
Broiler $\left(\mathrm{n}_{4}=16\right)$ & $39,391.00$ & $54,541.00$ & $38(6.62)^{* * *}$ \\
Layer $\left(\mathrm{n}_{5}=15\right)$ & $14,569.00$ & $17,746.00$ & $22(3.65)^{* *}$ \\
Cattle $\left(\mathrm{n}_{6}=12\right)$ & $4,162.00$ & $4,500.00$ & $8(2.03)^{* *}$ \\
Fishery $\left(\mathrm{n}_{7}=20\right)$ & $64,030.00$ & $113,041.00$ & $77(2.10)^{* *}$ \\
Crops $(\mathrm{N}=99)$ & $40,279.00$ & $77,9509.00$ & $57(2.37)^{* *}$ \\
\hline
\end{tabular}

Note: Figures in parentheses are t-values

$*, * *$ and $* * *$ significant at $0.10,0.05$ and 0.01 levels, respectively.

It was found that in livestock sector most of the farmers reared poultry. Further, the net income improvement in goat rearing was not prominent. Increase in number of goats and 
price were the reasons for this. However, cattle, layers and broilers gave significant but low impact on net income increase approximately in the order 8, 22 and $38 \%$, respectively.

Fishery sector showed a significant net income increase of nearly $77 \%$ with the implementation of micro-credit support. Moving from traditional fishing methods such as wooden boats and angle fishing activities towards the use of modern nets and one day boats for their fishing activities, increased frequency of fishing with improved fishermen corporative society's function on credit support were the reasons for this improvement. Fishing catch declined over time was also found in the study by Joseph (2007); overall these traditional sectors showed a significant increase in net income of $67 \%$ after the microfinance availability.

Most (90\%) of the young individuals expressed their inability to obtain training and microfinance support in new marketable skills such as vocational training in motor cycle repairing, agro-machinery, electrical, masonry, carpentry, among others. The lack of reliable baseline information, incomplete need assessment; targeting weaknesses and inefficiency in coordination are the contributory factors for the existence of livelihood gaps. Due to lack of employment most of the youth in the area look for odd job to earn a living.

\section{Revolving fund efficiency (RFE)}

Around $95 \%$ of the community in this area received microfinance support less than Rs. $30,000.00$ while only $2 \%$ of the community obtained more than Rs. 45,000.00 microfinance support. Mostly CBOs provided only less than Rs. 30,000.00 per beneficiary but banks provided more depending on the size of mortgage. Saving of $31 \%$ of the microfinance beneficiaries was less than Rs. 5,000.00.

The interest rate and average revolving period of the microfinance programmes operated in Kinniya were $14 \%$ and 12.56 months, respectively. The average saving of the beneficiaries was Rs. 2,064.00 per season. The amounts of microfinance support and repayment were Rs.17, 937 and 3,045, respectively. Due to wide difference in financial support for different sectors, there was high variation in the values estimated.

The average RFE per household was $0.32 \%$ with a wide range between $0.24 \%$ and $0.48 \%$. This indicates that it was not well adopted in practice. This may be attributable to the lack of responsiveness of the $\mathrm{CBOs}$

The $\mathrm{R}^{2}$ value of the model was $54.5 \%$ with the probability of less than $0.01 \%$ thus, the model was accepted. Due to high correlation existed between age and experience in employment and age experience were removed form the regression function. As seen from the result age, education and family income were important factors determining the revolving fund efficiency significantly at $5 \%$ level. These indicate the importance of awareness and market arrangement for improvement in the RFE. Savings had significant $1 \%$ level negative impact on RFE. This implies that farmers actually benefited from microfinance support. They made private saving outside the programme and there was lack of commitment to repay the loan obtained. The revolving fund suffered due to the above attitude of private saving. Further investigations revealed that this was due to the weakness of the CBOs and lack of awareness on the benefits to the whole community. 
Table 3. Regression analysis of factors affecting of revolving fund efficiency

\begin{tabular}{lccc}
\hline Predictor & Coef & SE Coef & P \\
\hline Constant & 12.768 & 5.769 & 0.029 \\
Family Size & 0.183 & 0.045 & 0.022 \\
Education & $0.117^{*}$ & 0.033 & 0.030 \\
Age & $0.067^{*}$ & 0.032 & 0.031 \\
Family income & $0.011^{*}$ & 0.004 & 0.007 \\
Interest rate & 0.131 & 0.224 & 0.560 \\
Revolving period & 0.351 & 0.498 & 0.483 \\
$\quad$ saving & $-0.030^{* *}$ & 0.010 & 0.002 \\
Microfinance support & -0.001 & 0.010 & 0.100 \\
Repayment amount & $0.006^{*}$ & 0.004 & 0.020 \\
$\mathrm{R}^{2}$ (adjusted) value & & & 0.545 \\
& & & \\
\hline
\end{tabular}

F- value 29.26 p- value 0.000 Number of Observation 99

$*, * *$ and $* * *$ significant at $0.10,0.05$ and 0.01 levels, respectively.

It was evident from further investigation that RFE cannot be sustained without improvement of livelihood and related infrastructure such as road to market and market arrangement. The members of the CBOs with revolving fund should be encouraged to engage to work together by joint buying of inputs and marketing their products.

\section{CONCLUSIONS}

Traditional farming and fishery both showed significant increase in income and savings, however, there existed significant gaps in other nontraditional sectors. RFE was significant but very low. Following considerations are needed for effective livelihood improvement though micro fiancé support: Effective capacity building of CBOs to operate revolving fund, value addition through food processing, vocational training and other similar activities for young people.

\section{ACKNOWLEDMENT}

The authors wish to thank the Coastal Community Development Project management and the participants for their support and cooperation in data collection of this study.

\section{REFERENCES}

Economic and Social Statistics of Sri Lanka. (2009). Central Bank of Sri Lanka.

Farming Matters. (2010), Thinking beyond credit, ILEIA publication, June. www.ileia.org 36 -39 .

Tilakaratna, G., Wickramasinghe, U. and, Kumara, U. (2005), Microfinance in Sri Lanka: A household level analysis of outreach and impact on poverty. 
International Fund for Agricultural Development, IFAD. (2006). Microfinance and institutional capacity development project in Anuradhapura, Sri Lanka.

ILO - Colombo The ILO Office for Sri Lanka (2006), Livelihood gap analysis. Five resettled DS divisions. Batticaloa district ILO Conference on Maritime Labour Convention (MLC 2006) ww.oit.org/public//english/region/asro/colombo/index.html

ITDG-South Asia (2005). Rebuilding Fisheries Livelihoods in Sri Lanka, Post-Tsunami Concept note. Coastal Conservation Department, Sri Lanka.

Joseph, L. (2007), Post-tsunami economic rehabilitation of fisheries sector in Sri Lanka challenges and way forward, FAO, www.humanitarian-srilanka.org.

Maeino, M. and Braidotti, G. (2010). Livelihoods lift with DIY water supply, Publication of Australian Center for International Development 2 March - April 2010.

www.aciar.gov.au $26-27$.

ProMiS - Promotion of the Microfinance Sector Sri Lanka, (2007), Microfinance and conflict in Sri Lanka, Towards a Sustainable Socio-Economic Development in the North and East. A position paper Colombo March, 2007.

Tsunami Affected Area Project, TAARP, (2005). Coastal Conservation Department, Sri Lanka. 